\title{
Identification of an Idiotypic Peptide Recognized by Autoantibodies in Human Immunodeficiency Virus-1-infected Individuals
}

\author{
Q. L. Wang, ${ }^{\star}$ H.-T. Wang, ${ }^{\star}$ Edwin Blalock,, Sybille Müller, ${ }^{\ddagger}$ and Heinz Köhler ${ }^{\S}$ \\ ${ }^{*}$ Markey Cancer Center and Departments of ${ }^{\ddagger}$ Medicine and ${ }^{\S}$ Microbiology and Immunology, University of Kentucky Medical Center, \\ Lexington, Kentucky 40536-0096; and "Department of Physiology and Biophysics, University of Alabama, Birmingham, \\ Alabama 35294-0005
}

\begin{abstract}
Antibodies against HIV-1 proteins in HIV-1-infected individuals share a cross-reactive idiotype defined by the monoclonal antiidiotypic antibody $1 F 7$ (5). Using a computer algorithm based on the molecular recognition theory, regions of inverse hydropathy between the variable sequence of $1 F 7$ and human monoclonal anti-HIV-1 antibodies were identified, which are assumed to be involved in idiotypeantiidiotype contacts. A peptide was designed from the proposed contact in the variable heavy chain framework 3complementarity determining region 3 (FR3-CDR3) of human antibodies and was synthesized. This peptide is recognized by the antiidiotype 1F7 and inhibits the binding of $1 F 7$ to human anti-HIV-1 antibodies which express the 1F7 idiotype. A survey of normal and HIV-1-infected sera revealed the presence of antibodies in infected sera which bind to the FR3-CDR3 peptide. The biological relevance of autoantibodies against a self idiotope associated with HIV1 infection is discussed in the context of the regulation of the antibody response to HIV-1. (J. Clin. Invest. 1995. 96:775-780.) Key words: HIV-1 • AIDS - autoantibody • idiotype $\cdot$ peptide
\end{abstract}

\section{Introduction}

The function of idiotypic networks has been discovered in a large number of experimental immune responses as well as in diseases (for review see reference 1). In several of these immune responses, idiotypes and antiidiotypes have been used to manipulate or induce immunities (for review see reference 2). A general obstacle in the idiotype network approach is the imprecise knowledge of idiotypic structures on immunoglobulins and $\mathrm{T}$ cell receptors. Recently, a new method has been used to identify the molecular contacts between $(\mathrm{CDRs})^{1}$ of idiotype

Address correspondence to Heinz Köhler, 205 Combs Research Building, Markey Cancer Center, University of Kentucky Medical Center, 800 Rose Street, Lexington, KY 40536-0096. Phone: 606-257-6486; FAX: 606-257-8940.

Received for publication 20 March 1995 and accepted in revised form 3 May 1995.

1. Abbreviations used in this paper: $\mathrm{CDR}$, complementarity determining region; FR, framework; HRP, horseradish peroxidase; IDR, idiotope determining region.

J. Clin. Invest.

(C) The American Society for Clinical Investigation, Inc. 0021-9738/95/08/0775/06\$2.00

Volume 96, August 1995, 775-780 and antiidiotypes (3). This approach is based on hydropathic complementarity, the so-called molecular recognition theory, which predicts the sequence regions involved in protein-protein interactions (4). This theory allows one to search protein sequences using a known ligand for regions which have inverse hydropathies and thus the potential for binding to the ligand probe. When applied to antiidiotypic antibodies, one can search for idiotope target region in the respective idiotypic immunoglobulins.

We have used this method (3) and searched for inverse hydropathies in human anti-HIV-1 antibodies for regions which are recognized by a murine monoclonal antiidiotypic antibody which reacts with a shared AIDS disease-specific idiotope $(5,6)$. This antibody, called 1F7, "sees" an idiotope expressed by human antibodies against HIV-1-encoded proteins and is only detected in individuals infected with HIV-1. For this study, the $V_{H}$ and $V_{L}$ cDNAs of 1F7 were cloned and sequenced. The sequence region predicted by inverse hydropathy for interaction with the variable regions of 1F7 are in the FR3-CDR3 regions of heavy chains of 1F7-positive human antiHIV antibodies (7). Here we show that in sera of infected individuals antibodies exist which bind to a peptide derived from the heavy FR3/CDR3 region of human anti-HIV-1 antibodies predicted as idiotypic target for the 1F7 antiidiotype mAb.

\section{Methods}

Sequence determination of the exon for $1 F 7 V_{H}$ and $V_{L}$. Total RNA was isolated from $1 \times 10^{7} 1 \mathrm{~F} 7$ hybridoma cells by the procedure described by Chomczynski and Sacchi (8). mRNA was prepared by passage through two cycles of chromatography on oligothymidylate-cellulose columns (9). First strand cDNA was synthesized using SuperScript Preamplification kit (GIBCO/BRL, Gaithersburg, MD). The DNA fragment encoding the $V_{H}$ of 1F7 was then amplified by PCR using the 5'primer GGGAATTCATGRAATGSASCTGGGTYWTYCTCTT and the 3'-primer CCCAAGCTTCCAGGGRCCARKGGATARACIGRTGG ( $\mathrm{I}=$ inosine, $\mathrm{R}=\mathrm{A}$ or $\mathrm{G}, \mathrm{Y}=\mathrm{C}$ or $\mathrm{T}, \mathrm{K}=\mathrm{G}$ or $\mathrm{T}, \mathrm{S}=\mathrm{C}$ or $\mathrm{G}, \mathrm{W}=\mathrm{A}$ or $\mathrm{T}$ ) corresponding to sequences of the leader (signal peptide) region, amino acids from -20 to -13 , and the $\mu$ constant region, amino acids 126-119. In addition, the 5'-primer contains the EcoRI site and the 3 '-primer contains a HindIII site, providing an alternative cloning strategy (Novagen, Inc., Madison, WI). To minimize the error rates in PCR amplification, $p f u$ DNA polymerase (Stratagene, Inc., San Diego, CA) was used for amplification. Mutant frequency with this thermostable DNA polymerase is $1 / 10$ compared with Taq DNA polymerase. The fragment of cDNA amplified was subcloned into pT7 plasmid and NovaBlue competent cells were transformed using a protocol provided by the supplier (Novagen Inc.). Plasmid DNA was prepared by miniprep procedure (9) and the DNA sequence of the doublestranded plasmid was determined by Sequenase Version 2.0 kit (U.S.B. Biologicals, Cleveland, $\mathrm{OH}$ ). The sequence of the DNA insert in the plasmid was determined from both orientations using $\mathrm{T} 7$ promoter primer (TAATACGACTCACTATAGGG) and U-19 primer (GTT- 
1F7: $\quad$ OVTLKESGPG ILOPSOTLSL TCSFSGFSLS TSGMGVSWIR OPSGIGI 50 IdB5.7: QVTLKESGPG ILQPSQTLSL TCSFSGFSLS TSGMGVSWIR QPSGBGLEWL 1F7: $\quad 51$ AHIYWDDKR YNPSLKSRLT ISKDTSSNOV FIKITSVDTR DTATYYCARR IdB5.7: AHISWDDDNL YNPSLKSRLT ISKDTSRNQV FLKITSVDTA DTATYYCARR IdB5.7: AHISWDDDNL YNPSLKSRLT ISKDT IdB5.7: EAGYGQYLGPLDLDY WGQGTSVTVS

b

1F7: DIVLTWSPAS LAVSLGQRAT ISCKASQSYD YDGDSYMWYQ QKPGQPPKLI M-T310 DIVLTOSPAS LPYSLGQRAT ISCKASOSLD YDGDSYMWYQ QKPGQPPKLI 1F7: 51 IYAASNLESG SOPGLVAVGL GTDFTLNIHP VEEEDAATYY COLCNEDPPT M-T310: IYAASNLESG IPARESGSGS GTDFTLNIHP VEEEDAATYY CQQSSEDPPT 1F7: FGAGTKLELK RA M-T310: FGGGTKLEIK RA

Figure 1. Translated amino acid sequence of $\mathrm{V}_{\mathrm{L}}(a)$ and $\mathrm{V}_{\mathrm{H}}(b)$. IdB5.7 $V_{H}$ is aligned with $1 F 7 V_{H}$ and M-T30 Vk with $1 F 7$ Vk showing highest homologies with 1 F7 chains. Underlined residues indicate amino acid differences.

TTCCCAGTCACGACGT). At least three clones were picked for sequence determination. The sequence of the 1F7 light chain was similarly determined.

Peptides. Peptide 422(LRSVDTAIYYCARL), 436(QLTSVKAVDTAIYYCARL), and control peptide 291 (CYSKNQRNESSHGGE) were synthesized on a 431A Peptide Synthesizer (ABI Advanced Riotechnologies, Inc., Columbia, MD) utilizing FMOC chemistry. p436 contains $\mathrm{NH}_{2}$-terminal additional sequence derived from 71-31 mAb; p291 is derived from the calmodulin-binding domain of rat plasma membrane $\mathrm{Ca}^{2+}$ ATPase isoform 3.

Peptide-binding ELISA. Plates were coated with $100-\mu$ l peptides at concentration of $10 \mu \mathrm{g} / \mathrm{ml}$, overnight at $4^{\circ} \mathrm{C}$. After blocking at room temperature for $1 \mathrm{~h}, 1 \mathrm{F7}$ at $0,20,40,60,80$, and $100 \mu \mathrm{g} / \mathrm{ml}$ or $0,0.01$, $0.1,1$, and $10 \mu \mathrm{g} / \mathrm{ml}$ were added and incubated at $37^{\circ} \mathrm{C}$ for $2 \mathrm{~h}$. After washing, peroxidase-labeled goat anti-mouse IgM-horseradish peroxidase (HRP) (1:1,000 dilution) (Southern Biotechnology Associates, Birmingham, AL) was used and left at room temperature for $1.5 \mathrm{~h}$. After washing as above, enzyme activity was revealed by $o$-phenylendiamine dihydrochloride substrate (Sigma Chemical Co., St. Louis, MO) reading at $490 \mathrm{~nm}$. Alternatively, human sera, 1:1,000 diluted, were added to peptide-coated plates. After washing 1:1,000 diluted goat anti-human IgG-HRP was added and ELISA was developed as above.

Id inhibition assay. To determine the idiotype specificity of rabbit anti-p422 sera, rabbit anti-p422 sera was added to p422-coated plates together with 1 F7 $(\operatorname{IgM}, \kappa)$ or TEPC $183(\operatorname{IgM}, \kappa)$ at different concentrations at $37^{\circ} \mathrm{C}$ for $2 \mathrm{~h}$. ELISA was developed with goat anti-rabbit HRP. Similarly, HIV + sera, 1:800 diluted, was added together with $1 F 7$ or TEPC 183 to p422-coated plates and ELISA was developed with goat anti-human Ig HPR (1:1,000 diluted). Inhibition rate was calculated using the equation:

$\%$ inhibition $=100 \times\left(1-\frac{\text { Absorbance with inhibitor }}{\text { Absorbance without inhibitor }}\right)$

Biotinylation of p422 and 1F7-binding assays. NHS-LC-Biotin was linked to p422 utilizing a commercial kit (Pierce Chemical Co., Rockford, IL). To measure the binding ability of biotinylated-p422 to 1F7, plates were coated with $1 \mathrm{~F} 7$ at $2 \mu \mathrm{g} / \mathrm{ml}$ overnight at $4^{\circ} \mathrm{C}$. Free sites were blocked at room temperature for $1 \mathrm{~h}$. Biotinylated-p422 was added and incubated at $37^{\circ} \mathrm{C}$ for $2 \mathrm{~h}$. Bound $\mathrm{p} 422$ was visualized by streptavidin-HRP (Southern Biotechnology Associates) and $o$-phenylendiamine dihydrochloride.
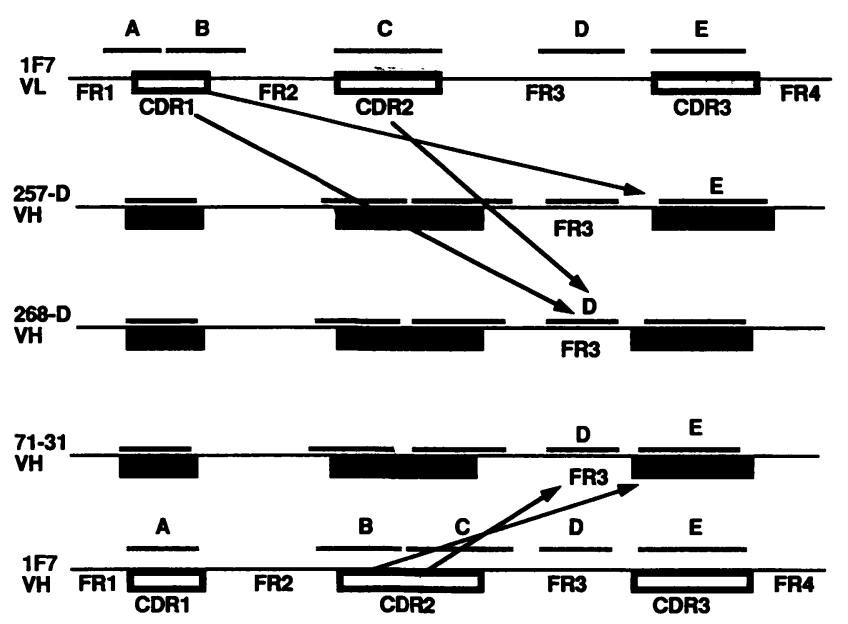

Figure 2. Schematic representation of predicted interaction between CDRs and FRs of the 1F7 antiidiotype antibody and $V_{H}$ regions of three human anti-HIV-1 antibodies. The open boxes are CDRs from $V_{L}$ and $V_{H}$ of 1F7, the closed boxes are CDRs from the $V_{H}$ of 257-D, 268-D, and 71-31. Arrows indicate complementary contacts. Regions with double lines and letters indicate IDR (14).

Rabbit anti-p422 antibodies. Rabbits were immunized with keyhole limpet hemocyanin-conjugated peptide, $100 \mu \mathrm{g}$ in CFA and IFA. After the 4th immunization the sera were tested. Rabbit serum was added to p422-coated plates and binding was detected by goat anti-IgG HRP (Southern Biotechnology Associates). Inhibition of rabbit sera binding by human HIV + sera was done by coincubation with rabbit anti-p422 sera. Inhibition of binding was calculated as described above.

Human sera. Serum samples from 30 asymptomatic HIV-1-infected individuals were purchased from North American Biologicals Inc., (Miami, FL). Serum samples from $25 \mathrm{HIV}-1$-infected individuals with confirmed clinical status of AIDS were obtained from Dr. Michael McGrath, UCSF, San Francisco, California. Plasma specimens and serum of babies perinatally infected with HIV-1 of $P_{1}$ and $P_{2}$ status were obtained from Dr. Savita Pahwa, North Shore University Hospital, Manhasset, New York, and Dr. P. A. Tovo, University of Turino, Turino, Italy.

\section{Results}

Cloning and DNA sequencing of $V_{H}$ and $V_{L}$ of $1 F 7$ antiidiotype antibody. The genes coding for the variable heavy and light chain domains of the 1F7 antibody were cloned using $V_{H}$ and $\mathrm{V}_{\mathrm{L}}$-specific primers. The nucleic acid sequence of the cDNA clones were determined using standard methods ( see Methods). The translated sequence of the variable regions of heavy and light chain are shown in Fig. 1, $a$ and $b$. Computer homology search of the Kabat data bank (10) indicated homologies for the heavy chain of 1F7 with an anti-Id antibody against $\alpha$ (16) Dextran antibody (11) and for the light chain with an antiCD4 antibody M-T380 (12).

Identification of idiotypic contact regions for $1 F 7$ and design of idiotope target peptide for 1F7. Regions of inverted hydropathy were searched for between the 1F7 antiidiotypic antibody and several human anti-HIV-1 antibodies to identify potential contact sites between the $1 \mathrm{~F} 7$ and anti-HIV-1 antibodies (3). The hydropathic profiles of the $1 F 7 V_{L}$ and $V_{H}$ were compared to the hydropathic profiles of the anti-gp120 (MN) mAbs, 268-D and 257-D, the anti-p24 mAb 71-31 and the antigp41 mAb 98-6 (7). Previously, we have found that these three 


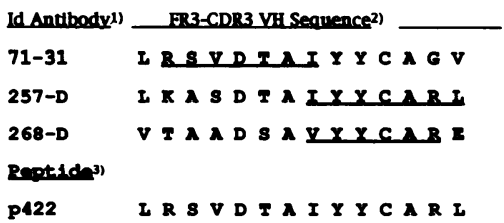

Figure 3. Design of 1F7 idiotope peptide. The CDR and FR regions of three 1F7-positive antibodies are shown. The underlined sequences were used to design the p422 peptide.

human mAbs, 268-D, 257-D, and 71-31 bind to 1F7, i.e., are $1 F 7$ Id positive (6). The hydropathic profile of a running window of at least six amino acids from 1F7 were scanned against the human anti-HIV-1 antibody sequences. 1F7 was also scanned against itself as control. The sequences were scanned in both directions. The indicated potential contact sites between 1F7 and its 1F7 Id-positive anti-HIV-1 antibodies are indicated schematically in Fig. 2.

Five regions from 1F7 match with five regions of the Id antibodies, most of which are at or near CDRs (Fig. 2). One hit occurs with 257-D, which overlaps with one of the hits from 268-D, and two hits occur with 71-31, both of which are in the framework 3 (FR3) of 71-31. The three mAbs, which are 1F7 positive, display hits with the CDR regions of $1 F 7$. In contrast, the $1 F 7$ negative $98-6 \mathrm{mAb}$ indicates complementary sites only in the in FR regions. Interestingly, 1F7 when scanned against itself, reveals a hit at FR2-L2 and H2. Since these two chains of 1F7 must associate to form a functional immunoglobulin molecule, it is not unexpected that some complementarity is displayed. The regions of complementarity that are presented on the surface of the Ig molecule, such as those at or near the CDRs, are expected to represent contact sites for other antibod- ies, i.e., antiidiotypic antibodies. Such sites have been previously described by us in generic terms as idiotope determining regions (IDR) on the basis of surface variability plots $(13,14)$.

A complementary idiotype target peptide for the $1 \mathrm{~F} 7$ was designed based on the IDRs of 257-D, 268-D, and 71-32 consisting of 14 amino acids. The peptide and its parental origin are shown in Fig. 3. This peptide is called p422.

Binding of $1 F 7$ to idiotope target peptide p422. To demonstrate that the 14 mer $\mathrm{p} 422$ peptide is the target for the antiidiotypic $1 F 7 \mathrm{mAb}$ we tested the binding of $1 \mathrm{F7}$ to p422. ELISA plates were coated with different amounts of $\mathrm{p} 422$ peptide or control peptides, p291 and p436. After washing, coated plates were incubated with 1F7 at different concentrations and bound $1 \mathrm{F7}(\mathrm{IgM}, \kappa)$ was detected with peroxidase-labeled goat antimouse IgM. As seen in Fig. $4 a, 1 \mathrm{~F} 7$ bound to p422-coated plates in concentration-dependent fashion and did not bind to the control peptide p291, or to p436 (Fig. 4, b and $c$. An unrelated mouse IgM, TEPC 183, was used as control in binding to p422-coated plates (Fig. $4 d$ ).

The p422-1F7 interaction was also demonstrated by reversing the ELISA configuration. Plates were coated with 1F7 and incubated with dilutions of biotin-conjugated p422 peptide. As seen in Fig. $5 a$, increasing concentrations of biotinylated p422 peptide added to 1 F7-coated plates produced increasing ELISA reading with enzyme-labeled avidin. Next, the specificity of $\mathrm{p} 422$ binding to $1 F 7$ was tested by inhibition experiments. As shown in Fig. $5 b$, the binding of 1F7 to 1F7 Id-positive antibodies in HIV-positive serum is inhibited dose dependently by $\mathrm{p} 422$ but not by the control peptide $\mathrm{p} 291$.

Collectively these data demonstrate that the 1F7 antiidiotype $\mathrm{mAb}$ binds to a peptide derived from the sequences of human mAbs which express the 1F7 idiotope. This also supports the
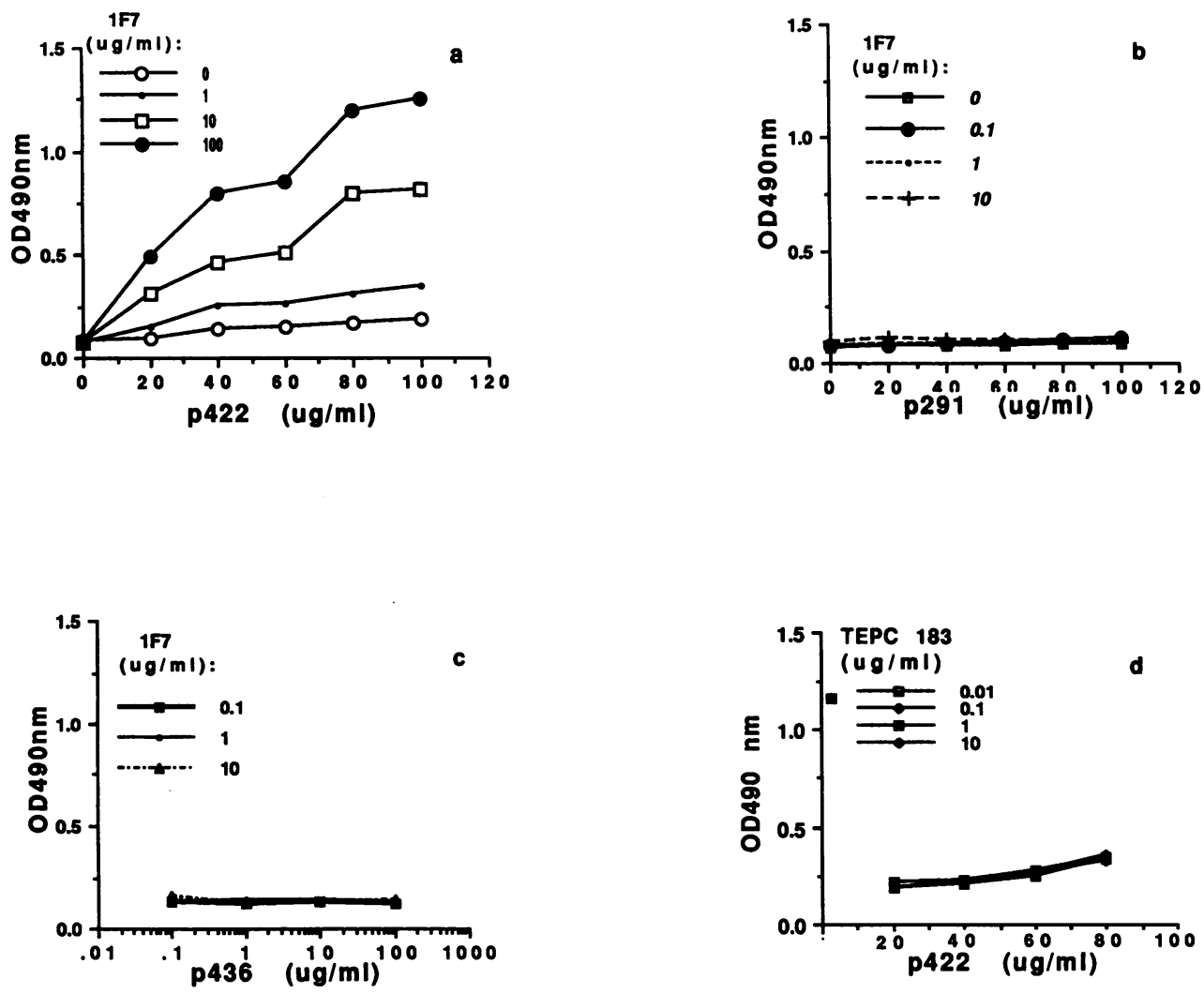

Figure 4. (a) Binding of 1 F7 to p422-coated plates. Plates were coated with increasing amounts of p422 peptides and different concentrations of $1 F 7$ were added. After washing ELISA was developed with goat enzyme-labeled anti-mouse IgM. ( $b$ and $c$ ) Binding of $1 \mathrm{~F} 7$ to control peptides p291 and p436 using identical ELISA. (d) Binding of TEPC 183 to $\mathrm{p} 422$-coated plates. ELISA as in $a$. 


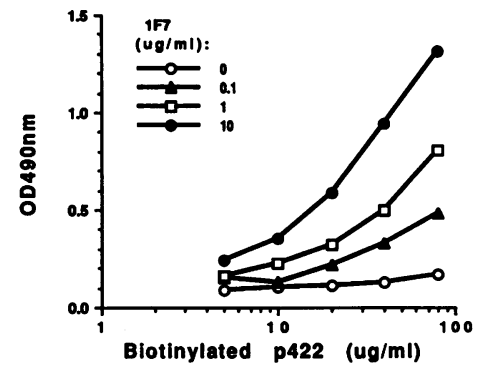

a

Figure 5. (a) Binding of p422-biotin conjugate to 1F7. Plates were coated with increasing amounts of 1F7; biotin-conjugated $\mathrm{p} 422$ peptide was added in different amounts and ELISA was developed using enzyme-conjugated avidine. (b) Inhibition of 1F7 binding to anti-HIV-1

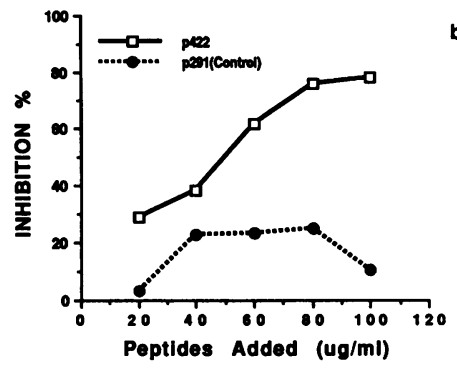

antibodies by $\mathrm{p} 422$ and control p291. Plates were coated with goat antiIgM; 1F7-positive human serum was coincubated with different amounts of p422 or p291 peptide. ELISA was developed with goat antiIgG-HRP.

utility of the inverse hydropathy relationship in protein-protein interaction as a method to search for sequences involved in protein binding.

To further confirm that the $\mathrm{p} 422$ peptide expresses the idiotope target for the 1F7 antiidiotype mAb, a polyclonal antibody against p422 was produced in rabbits. Rabbit anti-p422 serum binds to p422 coated plates (Fig. $6 a$ ), but does not bind to control peptide p291-coated plates. If p422 is the 1F7 idiotope or a major part of this idiotope, the binding of rabbit anti-p422 to p422 should be inhibited by 1F7. As seen in Fig. $6 b$, increasing amounts of 1F7 produced strong inhibition of p422 binding, while the unrelated mouse IgM TEPC 183 did not inhibit binding. These results demonstrate that the $\mathrm{p} 422$ peptide contains antigenic structures recognized by both the mouse monoclonal and the rabbit polyclonal antibody thereby confirming the idiotopic antigenicity of the $\mathrm{p} 422$ sequence.

Binding of serum antibodies from HIV-1-infected individuals to the 1F7 idiotopic peptide p422. 1F7 binds to a shared idiotope on anti-HIV-1 antibodies with different specificities $(5,6)$ and is only found in HIV-1 -infected individuals. Because of this broad reactivity and association with HIV infection, it is conceivable that the 1F7 idiotope is also the target for selfrecognition in infected individuals; in other words, autoantibodies might exist in seropositive individuals which recognize the 1F7 idiotope.

Sera from 51 HIV-1-infected individuals were tested for binding to p422-coated plates in ELISA. Fig. 7 a shows a representative ELISA with one HIV + serum in which anti-p422 activity is detectable. The binding is dilution dependent for both p422 and serum. A pool of sera from uninfected individuals shows no binding to p422 (Fig. $7 \mathrm{~b}$ ). No binding is detected with the HIV+ serum to the control peptide (Fig. $7 c$ ). The specificity of binding to p422 was tested by using the 1F7 antibody as competitor for HIV+ serum. As seen in Fig. $7 d$, $1 F 7$, but not the control IgM TEPC 183, competes with HIV+ serum for binding to $\mathrm{p} 422$ peptide.

Finally, the possibility that the binding of serum antibodies to $1 F 7$ may be nonspecific and unrelated to the p422 idiotypic peptide was excluded by showing that only the binding to 1F7
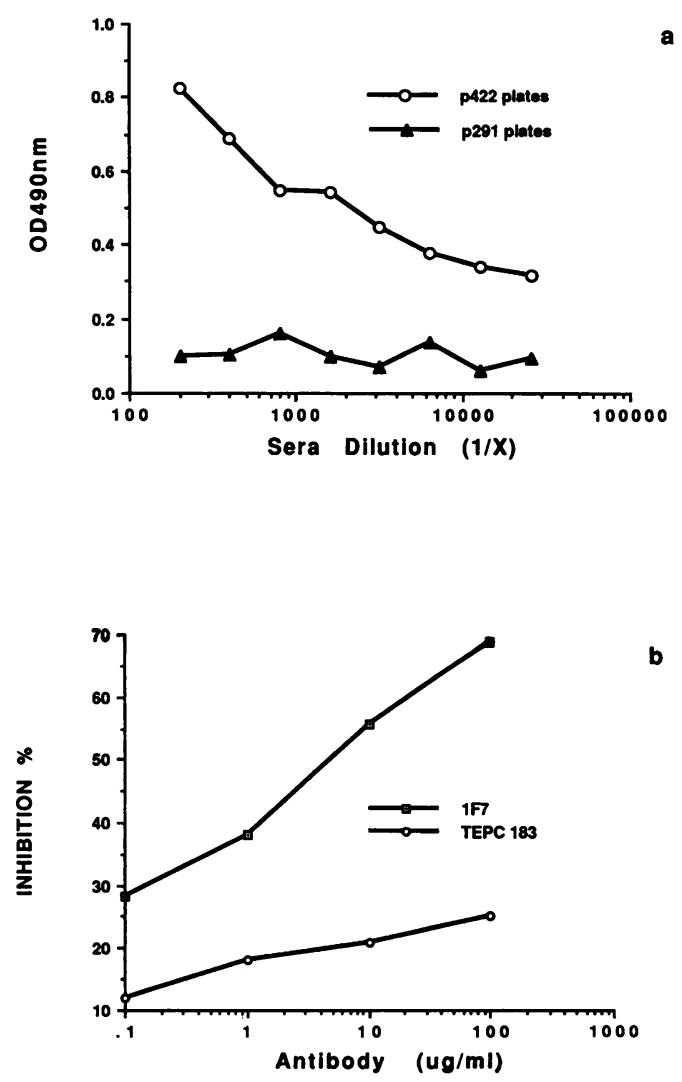

Figure 6. (a) Binding of rabbit anti-p422 serum to p422-coated plates. p422-coated plates were incubated with dilutions of rabbit antisera and ELISA was developed using enzyme-labeled goat anti-rabbit IgG. Sera were also added to p291-coated plates as control. (b) Inhibition of binding of rabbit anti-p422 sera to $\mathrm{p} 422$ by $1 F 7$ and TEPC 183 . Dilutions of rabbit sera were coincubated with different amounts of 1F7 or TEPC 183 and added to $\mathrm{p} 422$-coated plates.

can be inhibited by $\mathrm{p} 422$ and that the background binding to a control murine IgM, TEPC 183 , is not affected by $\mathrm{p} 422$ (Fig. 8).

Since not all HIV-1-infected individuals produce 1 F7 reactive antibodies, $(\sim 70 \%$ are $1 \mathrm{~F} 7$ positive $[5,6])$, it was of interest to ask whether the expression of 1F7 Id and autoantiId are associated or not. Serum samples from 1F7-positive and 1F7-negative individuals were assayed for binding to $\mathrm{p} 422$ peptide. As seen in Table I, 31 out of 51 1F7+ sera also contained anti-p422 antibodies; none of 4 1F7 Id-negative HIV seropositive sera react with $\mathrm{p} 422$. No binding to $\mathrm{p} 422$ was seen in nonHIV-1 infected 1F7-Id-negative seroreverting babies (Table I) and in seronegative sera from 20 adult HIV-seronegative blood donors (data not shown). We also tested sera from infected babies and found that 22/27 1F7-positive sera contained antibodies to $\mathrm{p} 422$ (Table I).

These results show that the autoantiidiotypic, i.e., 1F7-like, activity is correlated with the expression of the corresponding 1 F7 idiotype.

\section{Discussion}

In this report we describe a peptide which is recognized by antibodies in sera from HIV-1-infected individuals. This pep- 

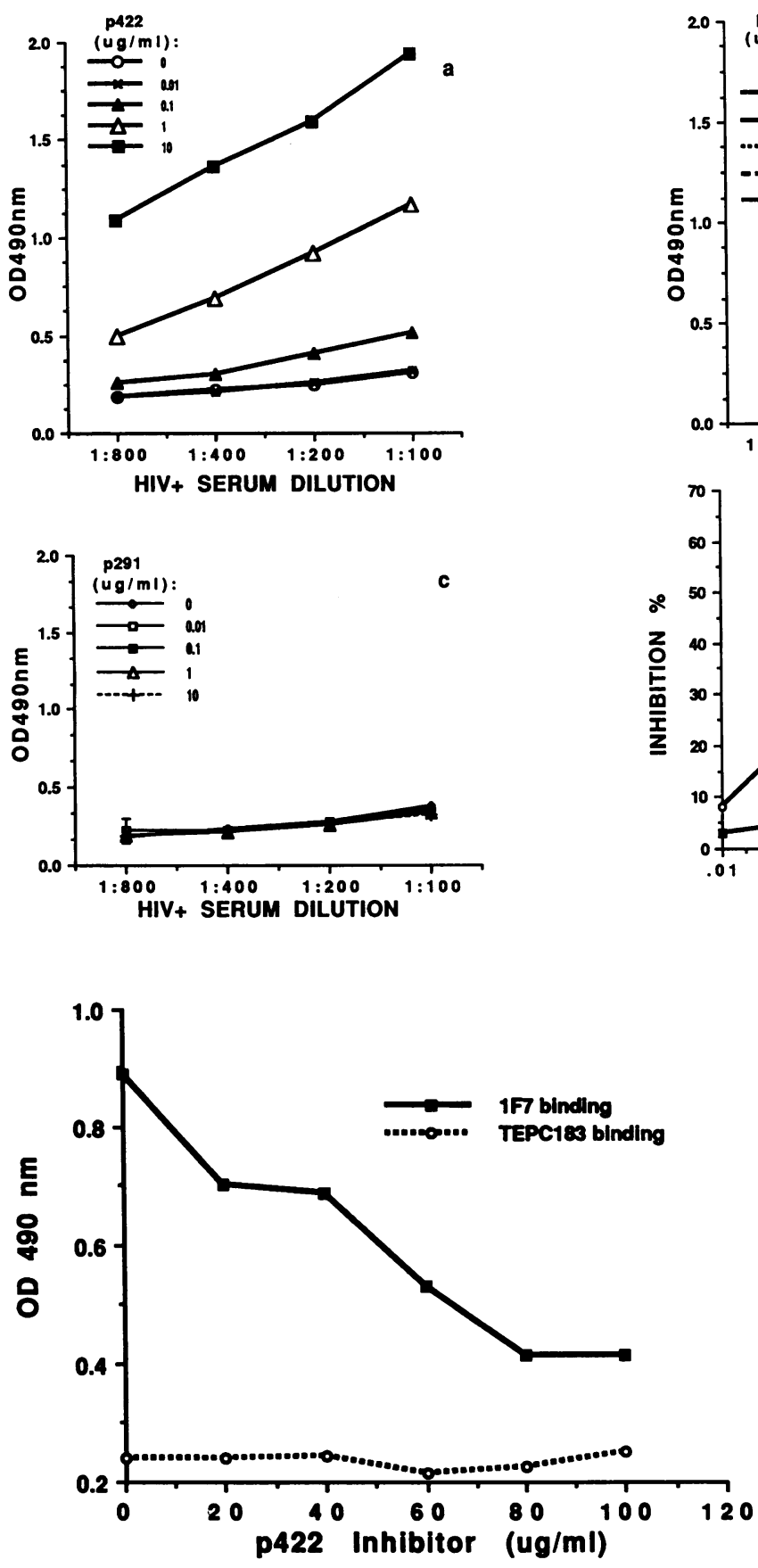

Figure 8. Inhibition of HIV + serum antibody binding to 1 F7 or TEPC 183 by p422. Plates were coated with goat anti-IgM, $1 F 7$ (IgM, $\kappa)$, or TEPC $183(\operatorname{IgM}, \kappa)$ were added together with increasing amount of p422; 1F7+ serum was added and ELISA was developed with goat anti-human IgG-HRP.

tide was designed from the sequence of human monoclonal antibodies against the viral envelope proteins gp120 and gp41, which react with a monoclonal antiidiotypic antibody recognizing a shared idiotope in sera of HIV-1-infected individuals (6). A search for inverse hydropathies $(3,4)$ between the monoclonal antiidiotypic antibody and human antienvelope antibodies indicated potential idiotope contacts which provided the sequence information for the peptide design. The sequence region used for the synthesis of the peptide comes from the FR3/
CDR3 regions of heavy chains of the human anti-HIV-1 antibodies.

The molecular recognition theory (4) has been used previously to generate antiidiotypic antibodies against autoantibodies and antibodies against hormones and receptors (for review see reference 3 ). This approach was used here to identify contacts between monoclonal idiotype and antiidiotype antibodies. This system is of considerable interest since the shared 1F7 idiotype is involved in cytotoxic effector function (Grant, M., M. Gomez, and F. Smail, unpublished data) and as target for enhancing apoptosis of $T$ cells from infected individuals (Müller, S., P. Brams, and H. Collins, unpublished data). The hydropathy analysis predicted the CDR regions which are involved in contacts between 1F7 and the human anti-HIV-1 antibodies. While the idiotope target region for $1 \mathrm{~F} 7$ could be mimicked by a peptide, peptides synthesized from 1F7 (antiId) CDRs failed to bind to anti-HIV-1 antibodies (data not shown). This suggests that the binding site of the 1F7 antiId is composed of more than one CDR arranged in a threedimensional configuration, a model, compatible with our current

Table I.

\begin{tabular}{lccc}
\hline \multicolumn{1}{c}{ Sera } & $\begin{array}{c}\text { No. of } \\
\text { 1F7 Id }+\end{array}$ & $\begin{array}{c}\text { No. of anti-p422 } \\
\text { (anti-Id) }\end{array}$ & $\begin{array}{r}\text { Percent Id+ } \\
\text { and anti-Id+ }\end{array}$ \\
\hline HIV-1+ adult* & 51 & 31 & 62 \\
HIV-1+ babies $^{\ddagger}$ & 27 & 22 & 81.5 \\
\hline
\end{tabular}

* None of 4 HIV-1 + 1F7 Id negative sera was anti-P422 (anti-Id positive). ${ }^{\ddagger}$ None of 251 F7 negative, sero-reverting baby sera was antiP422 (anti-Id) positive. 
understanding of antibody structure. In contrast, the idiotope target (idiotype seen by 1F7) appears to consist predominantly of a linear region which covers sequences from the framework and CDR. The combined involvement of framework together with hypervariable regions has been predicted by our previously described IDR model (14).

In the strictest sense these antipeptide antibodies are not autoantibodies since the peptides used were not derived from anti-HIV in sera studied here. However, because 1F7 binds to monoclonal human anti-HIV antibodies (6), which provided the sequence data for designing the $\mathrm{p} 422$ peptide, the human antipeptide antibodies are homologous autoantibodies. Therefore, we are using the term autoantibodies in this report.

The autoantibodies against a self IDR described here in sera from HIV-infected individuals are the second example of autoantibodies against a linear, peptide-defined, variable immunoglobulin epitope. Previously (15) we have identified another IDR consisting of CDR2-FR3 $V_{H}$ sequences recognized by antibodies in sera of certain mouse strains and of humans. This IDR is part of the murine germ line gene S107 Vl. In mice antibodies against phosphorylcholine, the dominant epitope of $\mathrm{C}$-polysaccharide, utilize the Vl germ line gene. While autoantibodies against CDR2-FR3 of S107 Vl recognize a nonmutated IDR, the antibodies against the p422 IDR peptide, described here, react with an IDR generated in part by somatic mutational and selective events. This is not unexpected since the infection with HIV-1 in evolution is a recent event not allowing for coselection of germ line-encoded IDRs. The 1F7 IDR described by the p422 peptide, is quite unique as it is not present on the 1F7 Id-negative human monoclonal anti-HIV-1 antibody 98-6 (6) and because a computer search of the sequence data bank (10) did not identify other antibodies with an identical sequence in this $\mathrm{V}_{\mathrm{H}}$ location except the IDR expressing 71-31 $V_{H}(7)$. The generation of the $p 422$ IDR by somatic and selective processes is further supported by the finding that this IDR is found on antibodies belonging to different $V_{H}$ gene families (16). On the other hand, the sequence of the 1F7 antiidiotypic antibody has high homologies in both chains with two other antibodies directed against members of the Ig superfamily, an anti-Id (11) and an anti-CD4 (12), respectively, see Fig. 1.

The reasons why the humoral immune response to HIV antigens selects for antibodies expressing the 1F7 IDR are unclear, but the participation of this epitope as described in several HIV infection-related immunological systems $(6,16$; Grant, M., M. Gomez, and F. Smail, unpublished data; Müller, S., P. Brams, and $\mathrm{H}$. Collins, unpublished data) suggests a biological activity of the 1F7 like autoantibodies in sera of infected individuals.

The murine 1F7 monoclonal antiidiotypic antibody reacts with anti-HIV-1 antibodies of different specificities $(5,6)$. 1F7 Id has been detected in all stages of HIV-1 infection (5; Grant, M., M. Gomez, and F. Smail, unpublished data), as well as in serum from gp120/160 vaccine volunteers and also in sera of experimentally HIV-1-IIIB-infected chimpanzees (17). 1F7 has also been shown to play a role in cytotoxic $\mathrm{T}$ lymphocyte activity as it suppresses cytotoxicity in vitro (Grant, M., M. Gomez, and F. Smail, unpublished data).

Collectively, the data on 1F7 reactivity with antibodies and $\mathrm{T}$ cells in HIV-1-infected individuals shows that this idiotype is involved in the immune response to HIV-1 infection. The finding of an autoantiidiotypic humoral response against the
$1 F 7$ idiotype, reported here, adds further evidence for a biological role of $1 F 7$ in AIDS. The significance of identifying the molecular target for 1F7 as a CDR-FR peptide lies in the potential to manipulate the immune response to HIV infection using peptide-based vaccines. What exactly the role of 1F7-like antibodies is remains subject to speculation at this time, and this question requires further studies.

\section{Acknowledgments}

We thank Marcia Ballard for help in preparation of the manuscript and Mike Russ, University of Kentucky Macromolecular Structure Analysis Facility, for synthesis of peptide p422, purification, amino acid analysis, and technical advice.

The work was supported by NIH grants NS 29719 to J. Edwin Blalock and CA 56701 to Heinz Köhler and American Foundation for AIDS Research grant number 500281-14-PG to Sybille Müller.

\section{References} 418:

1. Bona, C. A., and H. Köhler. 1983. Immune Networks. Ann. NY Acad. Sci.

2. Köhler, H., S. Kaveri, T. Kieber Emmons, J. W. Morrow, S. Muller, and S. Raychaudhuri. 1989. Idiotypic Networks and Nature of Molecular Mimicry: an Overview. Methods Enzymol. 178:1-36.

3. Maier, C. C., H. N. B. Moseley, S.-R. Zhou, J. N. Whitaker, and J. E. Blalock. 1994. Identification of interactive determinants on idiotypic-anti-idiotypic antibodies through comparison of their hydropathic profiles. Complementary Peptides: Application in Immunology and as Antibody Mimetics. ImmunoMethods. 5:107-113.

4. Blalock, J. E. 1990. Complementarity of peptides specified by "sense" and "antisense" strands of DNA. Trends in Biotechnol. 8:140-144.

5. Müller, S., H.-T. Wang, S. Kaveri, S. Chattopadhyay, and H. Köhler. 1991. Generation and specificity of monoclonal anti-idiotypic antibodies against human HIV-specific antibodies. J. Immunol. 147:933-941.

6. Wang, H.-T., S. Müller, S. Zolla-Pazner, and H. Köhler. 1992. Human Anti-HIV antibodies with different epitope specificity share common clonotypic markers. Eur. J. Immunol. 22:1749-1755.

7. Andris, J. S., S. Johnson, S. Zolla-Pazner, and D. Capra. 1991. Molecular characterization of five human anti-human immunodeficiency virus type 1 antibody heavy chains reveals extensive somatic mutation typical of an antigen-driven immune response. Proc. Natl. Acad. Sci. USA. 88:7783-7787.

8. Chomczynski, P., and N. Sacchi. 1987. Single-step method of RNA isolation by acid guanidinium thiocyanate-phenol-chloroform extraction. Anal. Biochem. 162:156-159.

9. Sambrook, J., E. F. Fritsch, and T. Maniatis. 1989. Molecular Cloning: A laboratory Manual, 2nd ed. Cold Spring Harbor Laboratory, Cold Spring Harbor, New York.

10. Kabat, E. A., T. T. Wu, H. M. Perry, K. S. Gottesman, and C. Foeller. 1991. Sequences of proteins of immunological interest. 5th ed. U.S. Department of Health and Human Services.

11. Perfetti, V., P. Borden, M.-M. Tao, S. L. Morrison, and E. A. Kabat. 1991. Specificity and variable region cDNA sequence of an isogeneic monoclonal antiidiotype to an anti-alpha (1-6) dextran. Mol. Immunol. 28:505-515.

12. Weissenhorn, W., W. Scheuer, B. Kaluza, M. Schwirzke, C. Reiter, D. Flieger, H. Lenz, E. H. Weiss, E. P. Rieber, G. Riethmueller, and U. H. Weidle. 1992. Combinatorial functions of two chimeric antibodies directed to human CD4 and one directed to the alpha-chain of the human interleukin-2 receptor. Gene. 121:271-278.

13. Kieber-Emmons, T., and H. Köhler. 1986. Evolutionary origin of autoreactive determinants. Proc. Natl. Acad. Sci. USA. 83:2521-2525.

14. Kieber-Emmons, T., and $H$. Köhler. 1986. Towards a unified theory of immunoglobulin structure-function relations. Immunol. Rev. 90:29-48.

15. Kaveri, S., C-Y. Kang, and H. Köhler. 1990. Natural mouse and human antibodies bind to a peptide derived from a germline variable heavy chain: evidence for evolutionary conserved self-binding locus. J. Immunol. 145:4207-4213.

16. Müller, S., H.-T. Wang, G. Silverman, G. Bramlet, N. Haigwood, and H. Köhler. 1993. B-cell abnormalities in AIDS: stable and clonally-restricted antibody response in HIV-1 infection. Scand. J. Immunol. 38:327-334.

17. Müller, S., D. Schwartz, H.-T. Wang, Q. Wang, H. Köhler, S. Pahwa, P.-A. Tovo, and P. Nara. 1995. Expression of an HIV-1 infection related idiotype/ clonotype in antibodies directed to envelope glycoprotein gp120 of HIV-1: early and concomitant idiotype increase in antibodies against the homologous vaccine strain. Vaccine Res. In press. 